International Journal of Social Sciences and Humanities
Available online at http://sciencescholar.us/journal/index.php/ijssh
Vol. 1 No. 2, August 2017, pages: 58 64
e-ISSN: 2550-7001, p-ISSN: 2550-701X
http://dx.doi.org/10.21744/ijssh.v1i2.43

\title{
Developing Communicative English Language Tests for Tourism Vocational High School Students
}

\author{
I Nengah Astawa a; Ida Bagus Nyoman Mantra ${ }^{\text {b; }}$ Ida Ayu Made Sri Widiastuti c; \\ Article history: Received 15 January 2017; Accepted in revised form 17 July 2017; Approved 14 August 2017; \\ Available online 30 August 2017
}

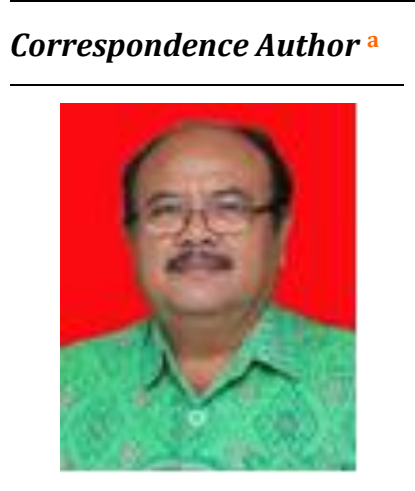

Keywords

Communicative;

Develop communicative;

Developing;

English language tests;

Vocational high school;

Abstract

The present study aimed at developing communicative language tests for vocational high school students. A Research and Development design was employed in this study with the primary target was to develop communicative English language tests. The main procedures in the development of the test include: (1) identifying objectives, (2) developing the test specification, (3) developing the communicative tests, (4) analyzing the results of the preliminary tryout of the communicative tests drafts, (5) revising the communicative test drafts, (6) trying out the communicative test drafts, (7) analyzing the results of the tryout of the communicative tests, (8) revising the communicative test drafts. Questionnaires and observation blanks sheet was used to gather comments, opinions, and criticisms on the draft of communicative tests from a number of selected experts. The analysis of the communicative tests tryout was done to ensure the validity, reliability, and practicality of the tests.

e-ISSN : 2550-7001, p-ISSN : 2550-701X(C Copyright 2017. The Author. SS Journals Published by Universidad Técnica de Manabí. This is an open-access article under the CC BY-SA 4.0 license (https://creativecommons.org/licenses/by-sa/4.0/) All rights reserved.

\section{Contents}

Abstract

1. Introduction

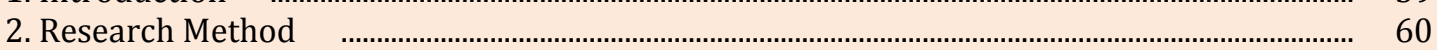

a Mahasaraswati University, Denpasar, Bali, Indonesia (nghastawa@ymail.com)

b Mahasaraswati University, Denpasar, Bali, Indonesia (bagusmantra@unmas.ac.id)

c Mahasaraswati University, Denpasar, Bali, Indonesia (misswidia@yahoo.co.id) 


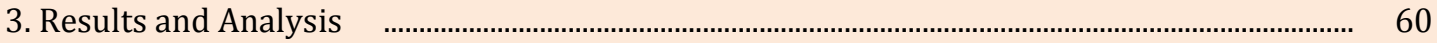

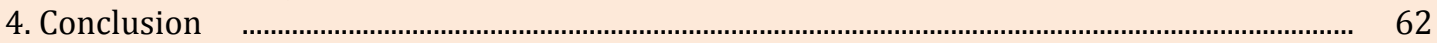

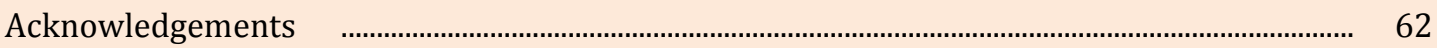

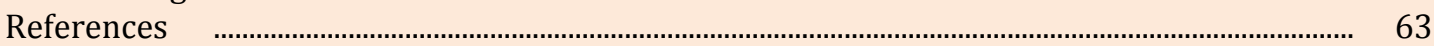

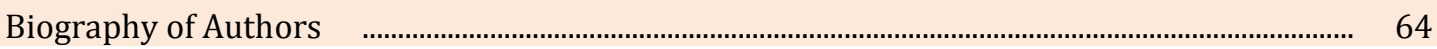

\section{Introduction}

Communicative language teaching approach requires that the teaching of English should enable students to master the communicative competence. Consequently, the objective of language teaching is to develop students' communicative competence. Communicative competence is the competence which enables students to transmit and interpret messages and give meanings in the interaction between individuals in a specific context. Moreover, as the consequences of communicative language teaching, the tests have to be in the form of communicative tests as well (Alptekin, 2002; Mantra, 2017). The tests should also be designed in respect to the four language skill (listening, speaking, reading and writing). In the same time, the tests should be able to measure the students' communicative competence realized as the four language skills and the competence suggested by school curriculum. Communicative language testing should be concerned with what the learner knows about the form of the language and how to use it appropriately in context and the extent to which the learner is able to demonstrate this knowledge in a meaningful situation (Nguyen, 2011).

Communicative Language Tests actually closely deal with the students' ability to perform their competence in meaningful communicative situations (Brown, 20104; Phan, 2008). Communicative language ability which consists of language competence, strategic competence, and linguistic competence also involves psycho-physiological mechanism in their usage (Laborda, Santiago, Juan, Álvarez, 2014). Therefore, the emphasis of communicative tests is not merely on linguistic accuracy but on the ability to demonstrate language ability effectively in particular situation (Barkaoui, Brooks, Swain, \& Lapkin, 2013). There are several features of communicative language Test, namely: (1) context has a very important role and is advocated in the assessment of communicative language ability, (2) authenticity of tasks and the genuineness of texts in tests is something that should be pursued though problematic in its definition and realization, (3) different tests need to be constructed to match different purposes, (4) tests of communicative language ability should be as direct as possible, (5) integrated testing of communicative language ability is suggested rather than separate skills testing, and (6) communicative tests need to take the holistic and qualitative assessment of productive skills. Additionally, language test designing should comply with several concepts that need to be considered such as the concepts of validity, reliability and practicality (García Laborda, Magal-Royo, de Siqueira Rocha, Jose Macario, \& Álvarez (2010).

The ability of the students to perform communicatively is essential to do due to the fact that we can only compete in the era of globalization if we have high ability English (Mantra, 2017; Widiastuti, 2016). Some factual evidence had proven that the competition is very tight and competitive in all areas of life (Astawa, 2008). Consequently, teachers should be able to determine the ability of the students in English communication. Tests that are used to measure the students' language performance should reflect the students' real current ability that is why the tests should be communicatively done. Moreover, the tests should in line with the students' real daily life (Widiastuti, 2016). Additionally tests should be designed based on the competence standard as suggested by the 2013 curriculum (Maba, 2017). In a certain nature, the standard is too high for the students to attain especially for those who are living in rural areas of Indonesia because of infrastructure limitation (Maba, 2017).

Respecting the essential factors of language assessment is an important stage in the process of language teaching and learning as it helps monitor students' educational progress

Astawa, I. N., Mantra, I. B. N., \& Widiastuti, I. A. M. S. (2017). Developing communicative English language tests for tourism vocational high school students. International Journal of Social Sciences and Humanities, 1(2), 58-64. https://doi.org/10.29332/ijssh.v1n2.43 
and evaluate the quality of school systems. It is necessary to measure students' achievement as teachers cannot understand the knowledge, abilities and skills of the students in their classroom without conducting assessment by administering tests. Therefore based on the phenomenon, the development of communicative English test is very urgent to be designed especially for students of tourism vocational school in order that the school graduates are able to work in various sectors of the tourism industry professionally. This communicative test was then constructed in the frameworks of communicative domains by integrating those domains into every steps of test construction.

\section{Research Method}

The present study made use of a Research and Development Design investigating the developmental process of communicative English tests construction. The stages of the communicative construction were mainly carried out in six steps of sequence, namely: (1) analyzing the relevant test models used by the teachers in tourism vocational schools, (2) planning competence and the standard to be measured, (3) designing the initial draft, (4) conducting test trial to the initial draft to limited number of subjects; (5) revising the initial draft based on the result of the test trial (6) re-examining the revised draft based on the results of the first trial. The steps Research and Development (R \& D) guided this study in conducting field study research to collect data on the test models. The data collected were then analyzed to construct a new model of communicative tests.

\section{Results and Analysis}

Communicative language tests are mainly designed to provide the teacher with information about the students' ability to perform in the target language in certain contextspecific tasks. This study concerns with developing communicative English language tests for Tourism vocational high schools. The tests under the discussion here are constructed on the basis of communicative language teaching principles. The test must strictly follow the guidelines of the school curriculum and should comply with the standard of competence determined by the authorities. The development of communicative English language tests are briefly discussed as the following.

The tests that have been collected from selected sample of tourism vocational high schools were thoroughly studied in depth analysis to get collective ideas of test models used by the teachers in assessing students' communicative ability in English. This study found that most tests used by the teachers in tourism vocational high schools were mainly in the form of multiple choice test and matching test. The language skills which were tested dominantly reading skill and written expression, there was neither writing test nor speaking test. Teachers however tested the students' vocabulary ability. This is understandable because vocabulary was judged to be the most essential language components. Most of the tests designed by the teachers contained vocabulary tests and the vocabulary which were tested were mainly general and basic vocabulary. The number of the tests was mostly 50 test items using four optional answers. Judging the characteristics of the four options, they have already been constructed according to the regulation of test options as commonly employed by teachers of high school. However, the degree of options variations and type of distracters needs to be revised in order that the test becomes more valid and reliable.

A good test must meet certain characteristics of a good test (Widiastuti, 2017). Characteristics of a good test include validity, reliability, objectivity, practicability, and economicality. The developed communicative English tests constructed for Tourism Vocational schools were designed in line with the curriculum requirements, especially standard competence, core competence, Learning Objectives, and learning indicators based curriculum for vocational high schools 2013. This is done to ensure that communicative tests were developed in accordance with the requirements of the School Curriculum, and to ensure that the communicative tests were developed to meet the needs of students. 
There were four of the Listening Comprehension Tests which were constructed, those was dictation, paraphrasing, note taking, and summarizing. The test was constructed in order that the students are able to comprehend various spoken texts in English. The most important thing is to understand contextual meaning and understand the general and specific information conveyed by the speakers. The test was then to be designed to indicate the students' ability in comprehending different things in different ways and in different situation presented in English. The main sources of the listening material were taken from recorded native speaker of English. The use of native speaker was intended to maintain the authenticity of the natural speech.

There were four speaking tests constructed in this communicative English test. Those are Role play, Re-Telling Text/Story, oral interview and oral presentation. The main reasons of choosing those test formats as communicative tests because of some reasons. Firstly, speaking test should provide opportunities for the students to present themselves in oral activities. Secondly, the activities should enable students to activate various elements of language being stored in their brains, the more they have chances to exercise them, the more fluency they attained. Therefore, communicative speaking tests should be designed to engage students in a variety of activities. The test being constructed in the present study were all involving students and activating their language elements.

Reading skill is very important skill for learners. Through the ability to read well, learners will be able to understand the texts well too. There are five types that can be developed in terms of communicative test. Those are reading aloud, true or false test, completion test, matching test, and answer question test. In reading skill, communicative English Test was designed to enable students to comprehend the content of the text thoroughly. They need to be able to scan the text for specific information. Students need to search for the information at a certain time or search quickly. This skill means that they do not have to read every word line by line. The students merely search for the particular information they need to find out.

In reading comprehension, students also need to be able to skim a text to get a general idea of the text. This skill is essential for the students to have because in real life they have to be able to use this skill to draw general conclusion or getting a bigger picture of real phenomena. Meanwhile students need to be able to scan specific information. This skills need to be nourished since a lot of things in life we really just scan them quickly to get what we intend to get.

The reading texts used as material for the communicative tests were authentic texts in other words, texts which are not written especially for language learners, but which are intended for any competent user of the language. However, at lower levels this can often present insuperable problems since the amount of difficult and unknown language may make the texts impenetrable for the students. The texts were taken from refutable resources and they were carefully selected to ensure their degree of authenticity. However how well the reading material were designed, again the most importantly is the students' ability to comprehend and relate their existing knowledge to link up all the utterances of the words in the text. Therefore, teachers should not only prepare the students with reading texts but they should also continually build up their students' ability in exercising their reading skills.

The students' ability to convey and express information, thoughts, ideas, ideas and desires in writing is continually necessary improved. To communicate in writing skills is necessary because of the growing needs written communication skills of learners in this millennium era. There are five types of writing tests developed for these communicative tests. Those are writing personal letter, writing permission letter, writing short message, writing invitation and greeting card, and Writing advertisement or announcement or Short Brochure. These types of writing tasks are very beneficial for the students to practice because they allow them express our feeling, hope, dream, and joys as well as our fear, angers, and frustration. Moreover, students should be able to present an idea, give an example, give a reason, and argue logically.

Astawa, I. N., Mantra, I. B. N., \& Widiastuti, I. A. M. S. (2017). Developing communicative English language tests for tourism vocational high school students. International Journal of Social Sciences and Humanities, 1(2), 58-64. https://doi.org/10.29332/ijssh.v1n2.43 
A good writing is very important in conveying a message (Chong \& Lee, 2012). Specific words are needed and combined to create sentences to convey ideas in order to be understood by the readers. A good writing must have a real honesty, clarity, and brevity. It must be constructed more carefully, concisely, and coherently to ensure the clear meaning. Therefore, new movement in language teaching and language assessment were started as a reaction to the old ways of teaching. At the present time, communicative teaching and communicative assessment were primary emphasized to be carried in all language classroom activities. This is due the fact that communicative teaching and communicative assessment strongly advantaged the students' communicative competence.

The communicative tests which were developed in this study were still paper based test, however in the near future this test should be developed in computer based assessment as the computer based assessment has certain nature of necessity and practicability. Some modification of the test types are necessarily carried out if further steps of assessment developed should be willingly undertaken for the sake of testing perfection.

\section{Conclusion}

In conclusion, testing the students' ability has progressed a long way since the beginning learning practices. Assessment in millennium era, teachers are more interested in how students use their knowledge of language in a communicative situation than a demonstration of the knowledge in isolation. It makes that the purpose of communicative language testing is achievable. However, it is a form of testing which, like any other testing, usually has problems associated with it, therefore at the end it is up to the teachers' responsibility to endeavor to find solutions to the problems. Consequently teachers should carefully design the test to eliminate the occurrence of problems. The present study was conducted as an effort to decrease the testing difficulty and obstacles encountered by the teachers in tourism vocational high schools by providing them a set of communicative language tests. Therefore the draft of communicative English language tests was expected to bring significant solution for the teachers. In regard to validity and reliability issues, this draft of the tests had been designed and consulted with several experts to ensure the suitability of the tests for the students of tourism vocational high schools. Since the tests were still in the form of first draft, revisions on several tests components were necessary to be done to make them more valid and reliable to assess the students' communicative competence.

\section{Acknowledgements}

The authors would like to express their profound gratitude to all educators, teachers, and researchers for their help in conducting this study. Deep sincere gratitude also is dedicated to all who have been endeavor their support, their contribution, and their valuable input during the writing of this paper. Sincere gratitude also goes to the editors who have reviewed and approved this article to be published.

\section{References}

Adetunji, A. T., Adetunji, A. V., Adeleke, E. O., \& Madubuike, S. C. (2017). Deregulation: The Effect of Market-led Approach to Nigerian Universities Management. International Journal of Social Sciences and Humanities (IJSSH), 1(1), 1-8.

Alptekin, C. 2002. Towards Intercultural Communicative Competence in ELT. ELT Journal, Volume 56/1 University Press.

Amerta, I. M. S. (2017). The Role of Tourism Stakeholders at Jasri Tourism Village Development, Karangasem Regency. International Journal of Social Sciences and Humanities (IJSSH), 1(2), 20-28.

Astawa, I. N., Mantra, I. B. N., \& Widiastuti, I. A. M. S. (2017). Developing Communicative English Language Tests for Tourism Vocational High School Students. International Journal of Social Sciences and Humanities (IJSSH), 1(2), 58-64. 
Astawa, Nengah. 2011. Implementasi Pendekatan Sosio-Kultural dalam Pengajaran "English for Tourism". Jurnal Santiaji FKIP Unmas Denpasar Vol 1 No.1

Barkaoui, K., Brooks, L., Swain, M., \& Lapkin, S. 2013. Test-Takers' Strategic Behaviors in Independent and Integrated Speaking Tasks. Applied Linguistics, 34(3), 304-324.

Basak, A., \& Khanna, K. (2017). A Study on the Selection Criteria of Different Hotels of Delhi NCR in Accordance to the HR Policies and Market Trends. International Journal of Social Sciences and Humanities (IJSSH), 1(1), 27-38.

Brown, Douglas H. 2004. Language Assessment: Principles and Classroom Practices. New York: Pearson Education.

Cedeño, M. L. D., Arteaga, M. G. D., Pérez, A. V., \& Arteaga, M. L. D. (2017). Regulatory Framework for Renewable Energy Sources in Ecuador Case Study Province of Manabí. International Journal of Social Sciences and Humanities (IJSSH), 1(2), 29-42.

Chong, S. X., \& Lee, C. 2012. Developing a Pedagogical-Technical Framework to Improve Creative Writing. Educational Technology Research and Development, 60(4), 639-657.

García Laborda, J., Magal-Royo, T., de Siqueira Rocha,Jose Macario, \& Álvarez, M. F. (2010). Ergonomics Factors in English as a Foreign Language Testing: The case of PLEVALEX. Computers \& Education, 54(2): 384-391.

Ghosh, C. (2017). A Study on-Evaluating Marketing Strategies Adopted by Home Appliance for Economic Development in India. International Journal of Social Sciences and Humanities (IJSSH), 1(1), 9-15.

Laborda, J. G., Santiago, M. L., Juan, N. O. d., Álvarez, A. Á. 2014. Communicative Language Testing: Implications for Computer Based Language Testing in French for Specific Purposes. Journal of Language Teaching and Research, Vol. 5, No. 5, pp. 971-975

Maba, W. (2017). Teacher's Perception on the Implementation of the Assessment Process in 2013 Curriculum. International Journal of Social Sciences and Humanities (IJSSH), 1(2), 1-9.

Maba, W., \& Mantra, I. B. N. (2017). An Analysis of Assessment Models Employed by The Indonesian Elementary School Teachers. International Journal of Social Sciences and Humanities (IJSSH), 1(1), 39-45.

Maba, Wayan. 2017. The Implementation of Education National Standard in the Instrument of School Accreditation of Bali Province Education Authority. International Research Journal of Engineering, IT \& Scientific Research (IRJEIS). Vol. 3 Issue 4, July 2017, pages: 1-6 (2017).

Maba, Wayan. International Journal of Social Sciences and Humanities. Teachers' Perception on the Implementation of the Assessment Process in 2013 Curriculum. Vol. 1 No. 2, August 2017, pages: 1-9 (2017).

Mantra, I.B.N. (2017). Promoting Primary School Teachers' Competence through Dynamic Interactive Workshop and Partnership International Journal of Linguistics, Language and Culture (IJLLC). Vol. 3, No. 1, January 2017

Nguyen, M. T. T., (2011). Learning to communicate in a globalized world: to what extent do school textbooks facilitate the development of intercultural pragmatic competence? RELC Journal 42 (1), 17 - 30

Phan, S. 2008. Communicative Language Testing. Hawai Pacific University. Tesol Working paper Series 6(1)

Sri Widiastuti, I.A.Md. (2017). Teachers' Understanding of Formative Assessment. Jurnal Bahasa dan Seni. Vol 45, No 1 Juni 2017.

Sri Widiastuti, I.A.Md.( 2016). EFL Teachers' Beliefs and Practices of Formative Assessment to Promote Active Learning. The ASIAN EFL Journal. Volume 3.

Suparsa, I. N., Mantra, I. B. N., \& Widiastuti, I. A. M. S. (2017). Developing Learning Methods of Indonesian as a Foreign Language. International Journal of Social Sciences and Humanities (IJSSH), 1(2), 51-57.

Suryasa, I. W., Prayoga, I. G. P. A., \& Werdistira, I. W. A. (2017). An Analysis of Students' Motivation Toward English Learning As Second Language Among Students In Pritchard

Astawa, I. N., Mantra, I. B. N., \& Widiastuti, I. A. M. S. (2017). Developing communicative English language tests for tourism vocational high school students. International Journal of Social Sciences and Humanities, 1(2), 58-64. https://doi.org/10.29332/ijssh.v1n2.43 
English Academy (PEACE). International Journal of Social Sciences and Humanities (IJSSH), $1(2), 43-50$.

\section{Biographyof Author}

\begin{tabular}{|l|l|}
\hline \hline & $\begin{array}{l}\text { Drs. I Nengah Astawa, M.Hum is a lecturer in English Education Study } \\
\text { program. He is a lecturer of diverse subjects related to English Education. } \\
\text { He has conducted extensive researches in various subjects related to } \\
\text { English language teaching and literature. His papers have been published } \\
\text { nationally and internationally in various reputable journals }\end{array}$ \\
\hline \hline & $\begin{array}{l}\text { Dr. Ida Bagus Nyoman Mantra, SH., S.Pd., M.Pd is a Doctor in in Linguistics } \\
\text { from Udayana University and holds master degree in education from } \\
\text { Ganesha Education University. He is a lecturer in English Education at } \\
\text { Mahasaraswati University, Denpasar, Bali. He is teaching English language } \\
\text { teaching methods, research methodology, curriculum and materials } \\
\text { development and text book analysis. Ida Bagus Nyoman Mantra, SH., S.Pd., } \\
\text { M.Pd has carried out several studies in language education, oral tradition } \\
\text { and human right laws. His study focus is on investigating functions, values } \\
\text { and meanings of Balinese oral tradition. His articles have been published in } \\
\text { several national education and linguistics journals. }\end{array}$ \\
\hline $\begin{array}{l}\text { Ida Ayu Made Sri Widiastuti is a doctoral student of language education at } \\
\text { State University of Malang. She has an extensive study on language } \\
\text { development and assessment. She is currently conducting in depth and } \\
\text { intensive study on various assessment types of English language teaching. } \\
\text { Her academic papers have been published by several national and } \\
\text { international publishers }\end{array}$ \\
\hline
\end{tabular}

